\title{
Práticas espaciais e usos nos espaços públicos das praças em capi- tais da Amazônia oriental brasileira: os casos de Belém e Macapá
}

\author{
Olavo Fagundes da Silva ${ }^{1}$
}

\begin{abstract}
1 Doutorando em Geografia Física pela Universidade de Coimbra e Doutorando em Desenvolvimento Sustentável do Trópico Úmido pela Universidade Federal do Pará, Mestre em Desenvolvimento Regional, Geógrafo. Pesquisador Bolsista do CNPq, Brasil. E-mail: olavo@unifap.br
\end{abstract}

RESUM 0: As cidades da Amazônia brasileira e mais especificamente duas capitais de sua porção oriental, Belém e Macapá, compartilham das mesmas águas da grande foz do Amazonas, mas também de novas dinâmicas espaciais urbanas. Este trabalho teve como objetivo analisar, avaliar e caracterizar as práticas espaciais em três praças na cidade de Belém e três praças na cidade de Macapá. Objetivou ainda, apontar elementos de estudo que pudessem servir como suporte à decisão no planejamento e desenvolvimento de políticas voltadas para a melhoria desses espaços públicos. A partir do estudo de três praças na cidade de Belém-PA e três na cidade de Macapá-AP, este trabalho avaliou a frequência de visitação e os usos desses espaços públicos no cotidiano. A coleta de dados e informações foi realizada a partir da abordagem de 102 frequentadores e através de registro fotográfico e de informações que denotassem os usos das praças. 0 trabalho resultou numa avaliação da frequência de visitação e tipificação dos usos dos lugares pesquisados, apontando práticas espaciais preponderantemente dominadas por atividades e grupos específicos. Esses grupos organizados reúnem-se quase sempre em determinados horários e dias da semana e ratificam forte comprometimento com os espaços públicos nas cidades alvo do estudo.

Palavras-chave: Praças. Belém. M acapá. Visitação. Usos

Spatial practices and uses in the public spaces of squares in capital of eastern brazilian Amazon: cases of Belem and Macapá

ABSTRACT: The cities of the Brazilian Amazon and more specifically two capitals of the eastern portion, Belém and Macapá, share the same waters of the great mouth of the Amazon, but also new urban spatial dynamics. This study aimed to analyze, evaluate and characterize the spatial practices in three squares in the city of Bethlehem and three squares in the city of M acapá. Aimed also point study elements that could serve as decision support in the planning and development of policies to improve these public spaces. From the study of three squares in the city of Belém-PA and three in the city of Macapá-AP, this study evaluated the frequency of visits and the uses of these public spaces in daily life. Data collection and information was made from the 102 regulars and through photographic records and information that observing the presence of the uses of squares approach. The work resulted in a review of the frequency of visitation and classification of the uses of the places surveyed, pointing spatial practices mainly dominated by specific activities and groups. These organized groups meet often at certain times and days of the week and confirm strong commitment to public spaces in target cities in the study.

Keywords: Squares. Belém. M acapá. Visitation. Uses 


\section{INTRODUÇÃO}

As cidades de Belém e Macapá são, respectivamente, capitais dos Estados do Pará e Amapá, na Amazônia oriental brasileira (Figura 1). Embora compartilhem de um meio físico muito semelhante, essas cidades experimentam processos de urbanização com certas peculiaridades. A capital paraense, seja pelo espraiamento de sua área metropolitana, seja pela capacidade de polarização regional, apresenta dinâmicas como as grandes obras de "revitalização" no centro, ou de infraestrutura viária entre o centro e as áreas periféricas, que imprimem à cidade, 0 ar de metrópole em profusão econômica. Em Macapá, a mais notória marca do processo de urbanização, talvez seja a recente verticalização dos bairros centrais e a criação de grandes espaços coletivos, como os shoppings centers nos antigos ou novos centros comerciais dessa cidade. Entretanto para além dessas formas físicas espaciais mais marcantes, o fenômeno urbano imprime de forma articulada com estas, cada vez mais, uma mudança de comportamentos e de hábitos entre os citadinos dessas capitais amazônicas.

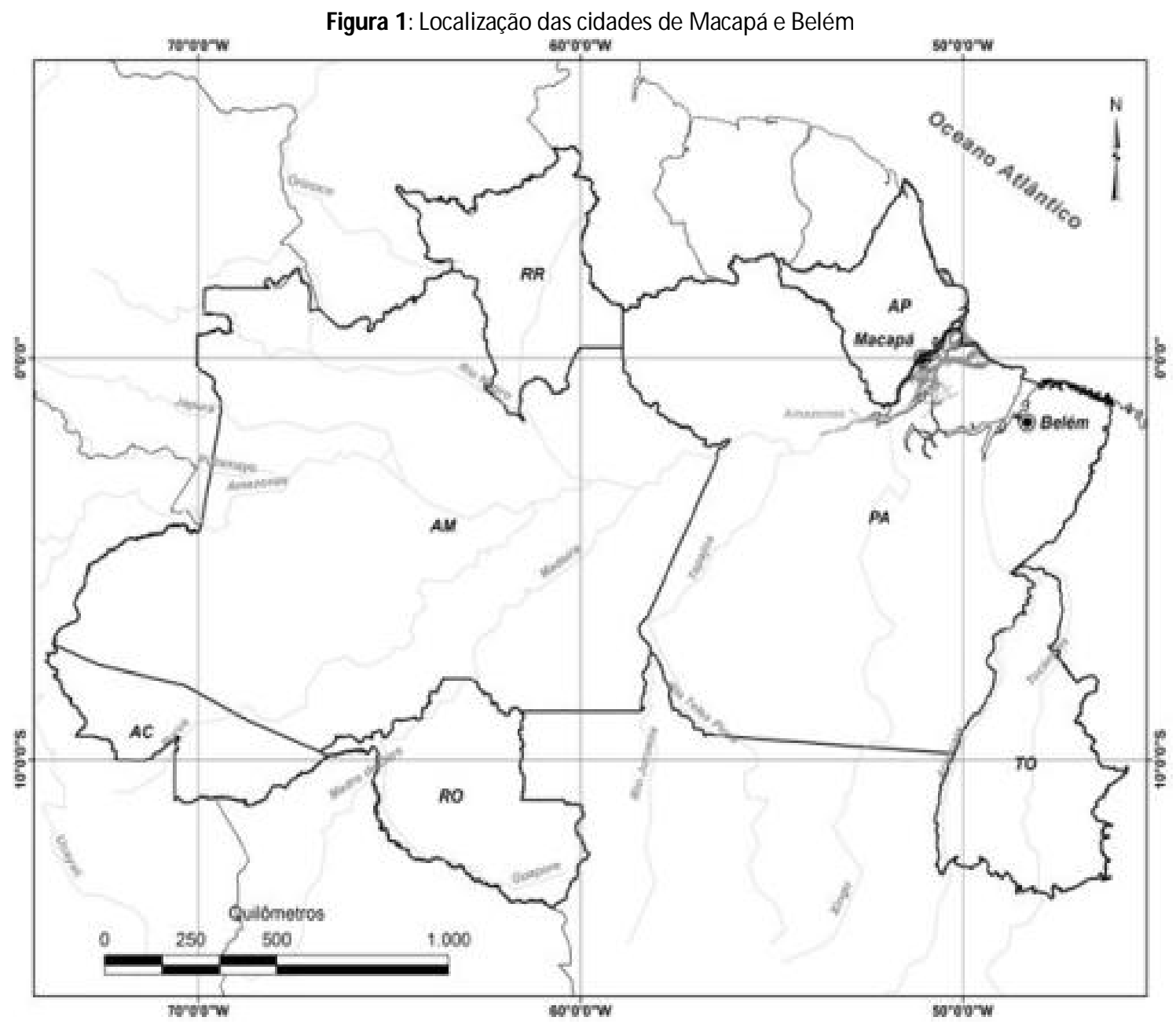

PRACS: Revista Eletrônica de Humanidades do Curso de Ciências Sociais da UNIFAP 
Na realidade urbana atual, tanto em Belém como em Macapá, ambas situadas em lados opostos da foz do grande Amazonas, aquele vínculo com as águas, traduzido nos equipamentos e pontos de conexão com o rio, como indicado por Trindade Jr (2013, p.68), parece ficar a cada dia mais restrito aos fluxos dos grandes ou médios volumes de produtos oriundos das trocas comerciais, que se intensificam. Mesmo no meio aquático, vocação natural das duas cidades o ritmo frenético das transformações físicas no espaço, ao que tudo indica, vai lentamente descaracterizando o direito a usos sociais mais estritos das águas como o deslocamento das pessoas e a provisão das pequenas comunidades ribeirinhas que circundam as duas cidades.

Pelo que se percebe numa rápida visita nos cais, nos portos, nas orlas de Belém ou M acapá, o citadino comum, em sua vivência cotidiana na atualidade está alienado ou sendo alienado das origens dessas cidades. As águas e o rio encontram-se relegados ao campo da contemplação, ou seja, podem ser observados, mas não podem ser usados, se pode olhar, mas não se pode neles mergulhar. Desta maneira, os rios que banham ambas as cidades estão ao mesmo tempo perto e inacessíveis.

A mudança na percepção do rio como parte da vida cotidiana prática, e, portanto como elemento importante nas práticas espaciais inerentes às cidades amazônicas, é provavelmente, consequência da perda do contato direto com as águas fluviais. Mas essa mudança é também, consequência da perda de memória, do refazer constante em ritmo acelerado dessas cidades, um acontecer ímpar, que, em geral, tem sido ditado pelas normas cada vez mais presentes do consumo e da privatização da vida cotidiana. Nos espaços públicos das praças e ruas numa grande metrópole como Belém ou em uma cidade média como Macapá, onde o citadino deveria encontrar guarida para os contatos sociais; a violência e o medo da violência também parecem ir imprimindo novas práticas espaciais.

Este trabalho teve como objetivo analisar, avaliar e caracterizar as práticas espaciais em três praças na cidade de Belém e três praças na cidade de Macapá. Objetivou ainda, apontar indicadores que pudessem servir como suporte à decisão no planejamento e desenvolvimento de políticas voltadas para a melhoria desses espaços públicos. Tomou-se como parâmetros de avaliação das práticas a frequência de visitação e os usos desses espaços públicos. Foram realizados levantamentos amostrais através da aplicação de questionários além do registro fotográfico e de informações dos usos desses espaços em caderneta de campo.

O planejamento metodológico da pesquisa foi feito de forma a tentar obter dados e informações que refletissem a frequência e diversidade de visitação e usos das praças nas duas cidades. Entre os meses de novembro e dezembro de 2015 foram visitadas e estudadas três praças em diferentes bairros nas duas cidades, considerando os horários em que supostamente esses lugares seriam mais frequentados. Em Belém a pesquisa foi realizada no Complexo Feliz Lusitânia, situado no Bairro Cidade Velha, na Praça Batista Campos, situada no Bairro homônimo e também na Praça do Jaú no Bairro Sacramenta. Na cidade de Macapá a pesquisa abrangeu a Praça do Forte, situ- 
ada no Bairro Central, a Praça da Conceição, situada no Bairro do Trem e a Praça Chico Noé, situada no Bairro do Pacoval. A pesquisa procurou assim, abranger o maior número e diversidade de lugares e seus frequentadores e, portanto, de usos possíveis.

A instrumentalização da pesquisa de campo centrada na avaliação de frequência de visitação e usos do espaço público das praças primou pela adoção de uma abordagem que permitisse interromper minimamente as atividades que as pessoas estivessem desenvolvendo, ainda que pressupondo-se que o espaço público das praças destina-se fundamentalmente a atividades relacionadas ao lazer e aos encontros, o que na essência significam atividades e momentos de descontração e teoricamente permitiriam uma abordagem com mais receptividade. 0 questionário entregue aos pesquisados, foi testado na Praça Batista Campos, com a aplicação de 20 instrumentos. Esse instrumento testado, além dos itens de identificação visando à estruturação da pesquisa, que já constavam no roteiro de entrevistas inicial, apresentava ainda sete questões (numeradas de 2 a 8 , nos gráficos apresentados no trabalho), sendo cinco com opções de respostas sim, não e duas com repostas de múltipla escolha.

M ostrando-se eficaz no teste aplicado na Praça Batista Campos, validou-se 0 instrumento e os dados e informações coletadas naquela praça. Em seguida procedeuse a aplicação do instrumento nos demais lugares estipulados. No total, foram aplicados 102 instrumentos, sendo 47 na cidade de Belém e 55 na cidade de Macapá (quadro 1).

Quadro 1: Distribuição do número de instrumentos aplicados, por data, horário, local e cidade.
\begin{tabular}{|c|c|c|c|}
\hline Instrumento & Quantidade & Local & Cidade \\
\hline Entrevistas & 7 & Complexo Feliz Lusitânia & Belém \\
\hline Questionário & 20 & Praça do Jaú & Belém \\
\hline Questionário & 20 & Praça Batista Campos & Belém \\
\hline Questionário & 22 & Praça da Conceição & Macapá \\
\hline Questionário & 20 & Praça do Forte & Macapá \\
\hline Questionário & 13 & Praça Chico Noé & Macapá \\
\hline
\end{tabular}

As coletas amostrais foram feitas de forma aleatória tendo como critério de sistematização apenas o cuidado de distribuir os instrumentos numa quantidade mais ou menos igual entre os gêneros e em diferentes faixas etárias. Além dos questionários foi feito o registro fotográfico dos lugares onde ocorreram as coletas, bem como 0 registro em caderneta de campo, das observações empíricas relevantes para a pesquisa. Dentre essas observações, priorizou-se o registro de ações e usos constatados no espaço pesquisado no momento das coletas, mas também se registrou quaisquer ações que denotassem uso pretérito, presente ou em perspectiva. No que concerne aos objetos espaciais para uso pelos frequentadores, também foram observados e registrados todos os equipamentos relacionados ao uso.

0 tratamento estatístico das amostras foi estruturado a partir da representação de cada lugar visitado nas diversas coletas. Embora durante as coletas amostrais tenha se procurado primar por uma sistematização baseada na equitatividade da representação 
dos gêneros esse critério ficou submisso ao caráter de aleatoriedade das amostras, não havendo coletas com quantidades iguais de instrumentos aplicados para os gêneros num mesmo espaço.

Os valores percentuais encontrados para a representação gráfica são relativos às respostas dadas para cada questão. Nas questões 3 e 4, com múltiplas respostas, os valores percentuais são resultantes da somatória das respostas dadas pelo total de participantes a cada opção de resposta da questão, sendo que neste caso cada participante poderia assinalar respectivamente, 6 opções (questão 3), 4 ou 1 opção (questão 4). Os percentuais totais apresentados para as duas cidades traduzem a soma dos valores das opções marcadas em cada questão, nos três lugares pesquisados em cada cidade.

O trabalho resultou numa análise das práticas espaciais com base na avaliação sistemática da frequência de visitação e dos usos desses espaços de forma a constatarse que em ambas as cidades a maior frequência de visitação e uso das praças está em boa medida relacionada a atividades grupais específicas, restritas a determinados horários e dias da semana. A existência dessas práticas espaciais em grupos e com atividades específicas refletem certa organização social nos usos dos espaços das praças por grupos que objetivam ter confiança e segurança nesses espaços durante os diversos usos nele engendrados, notadamente aquelas de maior frequência como a prática de esportes e as reuniões familiares ou ligadas a organizações como as Igrejas Cristãs.

Embora relacionados a atividades específicas, os usos dos espaços públicos nessas duas cidades capitais da Amazônia oriental brasileira ratificam a forte preocupação e comprometimento dos frequentadores com esses espaços. A presença relacionada a dias ou horários determinados, não implica necessariamente o abandono ou descaso com os espaços, mas, ao que tudo indica, uma nova percepção sobre eles, uma forma de reorganização que combate o seu abandono e em alguns, o descaso a que estão relegados pelo poder público.

Os grupos organizados e os movimentos que realizam nas praças de Belém e $\mathrm{Ma-}$ capá hoje podem ser o ponto inicial para repensar a valorização pública do espaço das praças e quiçá também das ruas e calçadas dessas cidades. Como bem afirma Trindade Jr (2013, p.68) em relação a Belém, essas capitais "nasceram das águas" e como as águas da imensa foz do Amazonas que as alimenta, tem o espaço de suas praças banhados pela ampla gama de percepções e atividades com valor de uso dos grupos e pessoas que nelas interagem.

Para atingir os objetivos traçados na pesquisa, o trabalho foi organizado em cinco tópicos, no primeiro se realiza a revisão dos conceitos norteadores. No segundo e terceiro tópicos se analisa, respectivamente, os resultados referentes aos dados e informações coletados e tratados sobre as práticas espaciais em ambas as cidades. No quarto se realiza um comparativo entre os resultados encontrados para as duas cidades e no quinto tópico se discute os problemas mais comuns às práticas espaciais nas praças e as políticas públicas a elas relacionadas. 


\section{MEIO URBANO E A PRÁTICAS ESPACIAIS}

0 processo de urbanização das sociedades contemporâneas atinge sua plenitude nas cidades, mas espraia-se pelos mais remotos espaços no planeta. Embora geradas na cidade, as variáveis urbanas transformam as sociedades imprimindo seus ritmos mesmo em lugares com forte presença da tradição ou relativamente isolados do ponto de vista físico, como os longínquos interiores amazônicos. Se mesmo nos interiores há testemunhos presentes da urbanização, as cidades da Amazônia Brasileira há muito vêm experimentando a intensificação crescente desse processo, que se expressa tanto nas formas quanto nas relações sociais que configuram os espaços dos seus centros urbanos.

As dinâmicas sociais que se desenvolvem em espaços singulares como as praças, levam à necessidade de retomada da noção de apropriação pública dos espaços da cidade. Como já afirmara David Harvey (2014, p.135): "A cidade é o lugar onde as pessoas de todos os tipos e classes se misturam, ainda que relutante e conflituosamente, para produzir uma vida em comum, embora perpetuamente mutável e transitória." Para 0 autor, essa vida em comum está baseada na existência de elementos comuns, que não podem ser entendidos como coisas específicas, ativos ou mesmo processos sociais em sí, “... mas como uma relação social instável e maleável entre determinado grupo social autodefinido e os aspectos já existentes ou ainda por criar do meio social ou físico, considerada crucial para a sua subsistência" (op. cit. p.138). Portanto, os comuns de acordo com Harvey são elementos imprescindíveis à subsistência de um grupo social e que só podem ser entendidos dentro de um contexto histórico e espacial.

O espaço físico, nem sempre pode ser considerado um comum, quando se consideram as implicações políticas e jurídicas aos quais está atrelado. Entretanto, é no espaço absoluto ou espaço área, que ocorrem os fenômenos biológicos e os arranjos físicos processados a partir das relações sociais e sociais-naturais. É no espaço físico que ocorrem, segundo Gomes (2012,p.21) “... as práticas sociais, a condição necessária para que estas práticas existam e o quadro que as delimita e lhes dá sentido".

Souza (2008, p. 79), por sua vez, entende que, esse espaço físico, concreto, para além dos fenômenos biológicos, abriga também a cena pública, ou esfera pública, que nada mais é que "as condições que propiciam a interação e indivíduos, que, com uma maior ou menor liberdade, expressam seus pontos de vista, articulam suas demandas, negociam seus conflitos, vêem e são vistos". Para este autor (op. cit.), a dimensão física do espaço e a cena pública encontram-se intimamente articulados dando significado à noção de espaço público que teria no espaço físico a sua face material e na cena pública, a face imaterial.

De acordo com Gomes (2012, p.30), o espaço apropriado e normado pelos grupos sociais nas cidades torna-se público na medida em que as dinâmicas sociais que nele ocorrem pressupõe usos coletivos ainda que regulados por um contrato social, ditado 
e inerente aos seus frequentadores. Nos espaços públicos das praças e ruas numa grande metrópole como Belém ou em uma cidade média como Macapá, onde o citadino deveria encontrar guarida para os contatos sociais; a violência e o medo da violência parecem ir imprimindo novas práticas espaciais. Este trabalho procurou estudar essas práticas espaciais em três praças na cidade de Belém e três praças na cidade de Macapá, tomou-se como parâmetros de avaliação a frequência de visitação e os usos desses espaços públicos.

0 urbano se constitui de formas, funções, estruturas e processos gerados a partir das cidades. Não se trata apenas de objetos ou produtos gerados nas cidades, mas também de ações que nela se desencadeiam e a partir dela se reproduzem nos demais centros urbanos ou mesmo em áreas consideradas como caracteristicamente rurais. A prática espacial é a primeira condição nos arranjos espaciais urbanos e, de acordo com Lefebvre (2006, p.65), "ela o põe e o supõe, numa interação dialética: ela o produz lenta e seguramente, dominando-o e dele se apropriando".

A prática espacial, segundo Lefebvre (2006, p.68) "engloba produção e reprodução, lugares especificados e conjuntos espaciais próprios a cada formação social, que assegura a continuidade numa relativa coesão." As práticas espaciais, portanto, são resultantes da vivência e percepção do espaço pela sociedade ou pelos indivíduos em suas relações. 0 conceito associa desta maneira, a "realidade cotidiana" e a "realidade urbana". A percepção do espaço como totalidade em construção, conforme afirma Santos (1999).

Se a percepção do espaço assegura a continuidade das relações socioespaciais, as práticas espaciais abrem caminho para o espaço da representação. Para Lefebvre (2006) o espaço da representação, exprime as experiências vividas e nessas vivências, pode estar o ponto de partida para qualquer discussão que pretenda prover alguma transformação do urbano.

Nas cidades, o valor de troca faz parte do cotidiano, porque o cidadão vive cercado de da natureza comercial que caracteriza o espaço da cidade, repensar o valor de troca, tão marcante, para um valor de uso, mais generoso e socialmente inclusivo na contemporaneidade é tarefa essencial na transformação do urbano. Se as sociedades tornaram-se urbanas, um novo olhar sobre o urbano deve ser lançado, um olhar que valorize a vida pública diante da sufocante apropriação, feita a todo o vapor, pelas mais diversas facetas assumidas pelo modo de produção alienante em que estamos mergulhados.

Por onde começar a estudar as práticas espaciais no espaço público das cidades? 0 que perceber? As práticas espaciais como instrumentos de interação denotam o espaço público, revelam a construção social do espaço entre os agentes envolvidos, como bem afirma Leite (2004, p.287). Então se faz necessário inferir quais práticas são predominantes nos lugares, quais as "convergências simbólicas" e as experiências compartilhadas nesse processo de construção ou reconstrução do público no espaço das cidades. 


\section{VISITAÇÃO E USOS DAS PRAÇAS NA CIDADE DE BELÉM}

No comparativo entre os lugares pesquisados em Belém os usos mais comuns refletiram diretamente a frequência de visitação. Nas praças Batista Campos e do Jaú, respectivamente $90 \%$ e $70 \%$ dos frequentadores são habituais, pois nesses lugares, prevalecem mais usos relacionados a hábitos de maior frequência durante a semana. Na Praça do Jaú, usos como a prática de esportes (68\%) ainda que frequentes, estão relacionados a determinados horários (Gráfico 1 ).

Gráfico 1: Comparação dos percentuais de respostas sobre a frequência de visitação, motivação e percepção de espaço público nos lugares pesquisados em Belém.

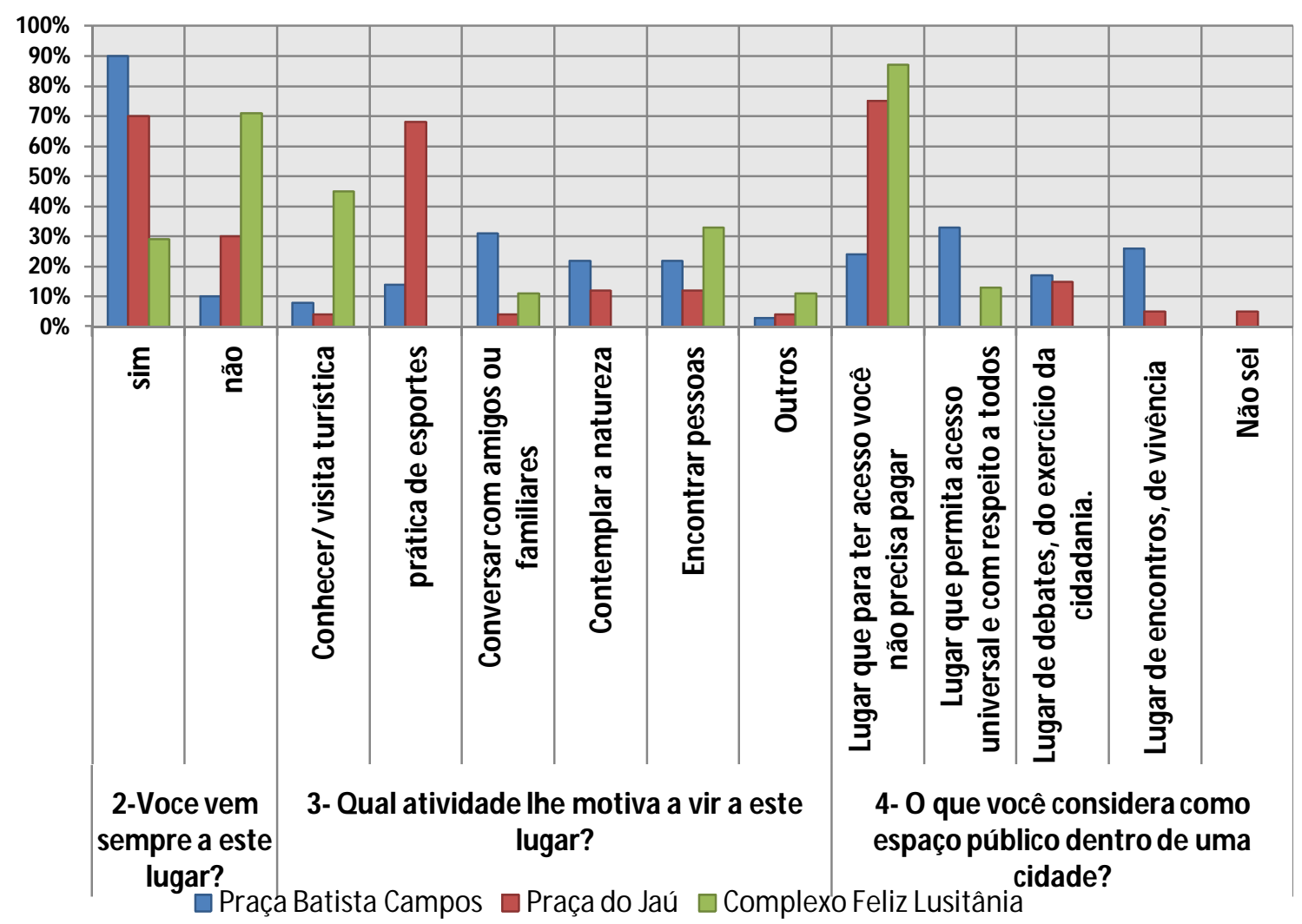

$\mathrm{Na}$ Praça Batista Campos, prevalecem os usos menos relacionados a horários como conversar com amigos (32\%), contemplar a natureza (18\%) e encontrar pessoas (27\%). No complexo Feliz Lusitânia, mais de $40 \%$ dos frequentadores afirmaram que estavam ali para conhecer ou realizar visita turística e menos de $30 \%$ afirmaram visitar com frequência o lugar, inferindo-se uma visitação voltada a pessoas com pouca ligação ao lugar ou à cidade (Gráfico 1, questões 2 e 3).

A percepção da esfera pública subjacente e inerente ao convívio nas praças, como elemento definidor de espaço público e a habitualidade dos usos também tem importância fundamental para a compreensão das respostas dadas pelos pesquisados. $\mathrm{Na}$ Praça do Jaú e no complexo Feliz Lusitânia, onde prevalecem os usos determinados 
pelas atividades de visitação turística e de prática de esportes, relacionados a horários, a noção de espaço público está atrelada ao livre acesso (75\% e 87\% respectivamente). Já na Praça Batista Campos onde os usos frequentes (menos relacionados a horários) prevalecem, surge a necessidade do acesso universal e respeitoso (32\%), do debate e exercício da cidadania (18\%) e dos encontros e da vivência [27\% (Gráfico 1, questão 4)].

No complexo Feliz Lusitânia a presença de vigilância privada para resguardar o patrimônio público e ordenar 0 acesso aos lugares parece garantir aos frequentadores maior sensação de segurança ( $42 \%$ se sentem seguras e $58 \%$ se sentem seguras em determinados horários ou dias da semana). Já na Praça Batista Campos a permanência do público ao longo do dia também assegura maior confiança entre as pessoas ( $50 \%$ dos pesquisados sempre se sentem seguros e $42 \%$ se sentem seguras em determinados horários ou dias da semana). Na Praça do Jaú, mais afastada do centro da cidade e submetida a um regime de usos relacionados a determinados horários, a maioria das pessoas (65\%) afirmou que não se sente segura (Gráfico 2, questão 5).

Gráfico 2: Comparação dos percentuais de respostas sobre a sensação de segurança, reconhecimento do espaço público, responsabilidade com a preservação e reconhecimento da importância para uma vida mais saudável na cidade de Belém.

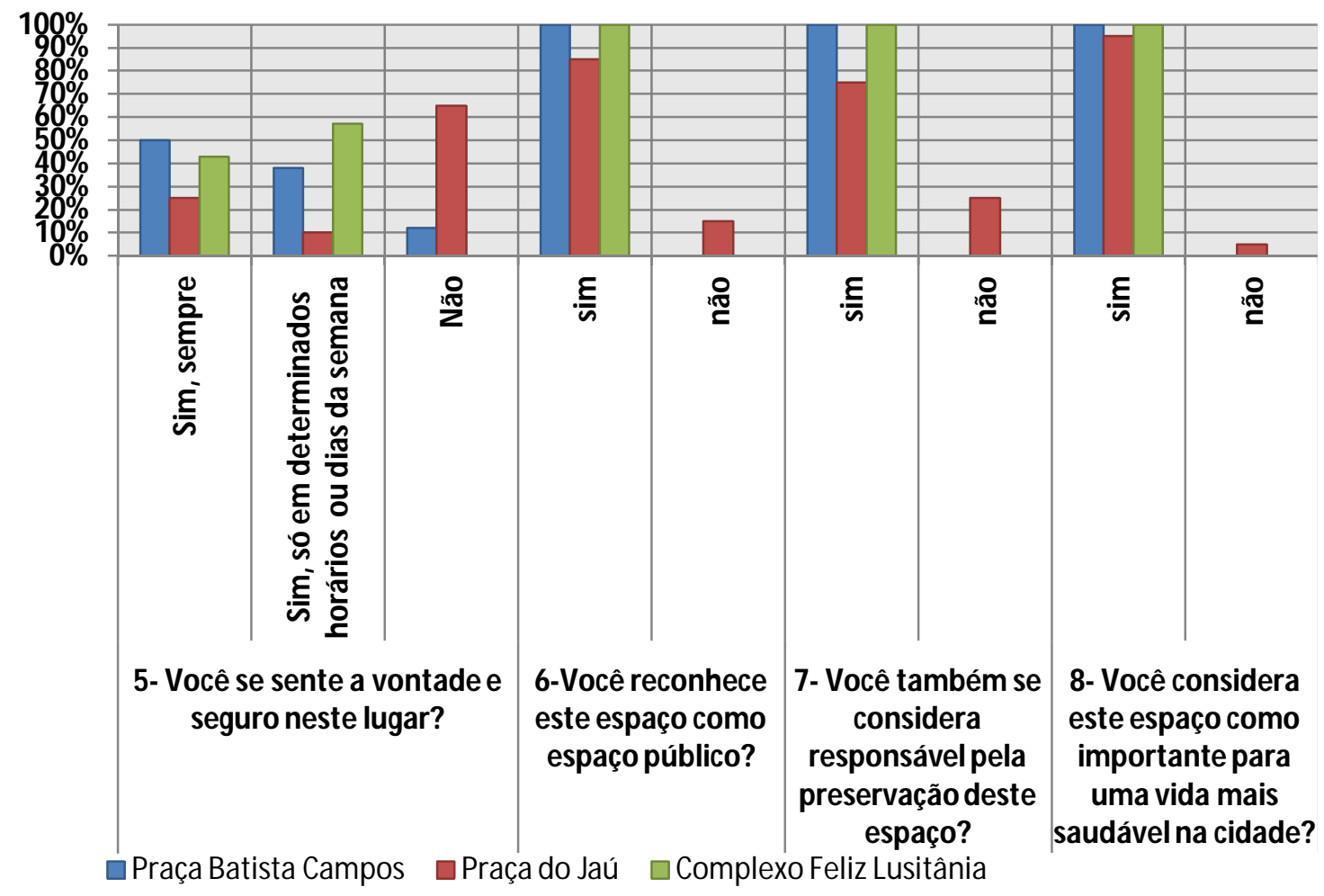

Nos três lugares pesquisados em Belém há praticamente unanimidade entre os pesquisados quanto ao reconhecimento destes como espaço público ( $100 \%$ na Batista Campos, $85 \%$ na Praça do Jaú e 100\% no Complexo Feliz Lusitânia). Quanto ao comprometimento com sua preservação (100\%, $75 \%$ e $100 \%$ respectivamente) e importância para uma vida mais saudável nas cidades (100\%, 95\% e 100\%), há pratica- 
mente unanimidade de compromisso com esses espaços entre os frequentadores (Gráfico 2, questões 6,7 e 8).

Complexo Feliz Lusitânia

Situado na Cidade Velha, o complexo compreende uma praça que conecta o público e o privado numa miscelânea resultante de um projeto de "revitalização". Na área pública, a praça, arborizada e florida, liga numa harmonia paisagística o Forte do Presépio (Figura $1 \mathrm{~A}$ ) e prédios antigos da administração pretérita de Belém. Adjacentes à praça principal (Figura 1B), corredores públicos que funcionam como extensão desta, conectam a um hotel e a um restaurante sob administração privada.

Figura 2: Vista do Portão principal do Forte do presépio $(A)$ e da praça em frente ao Forte(B).

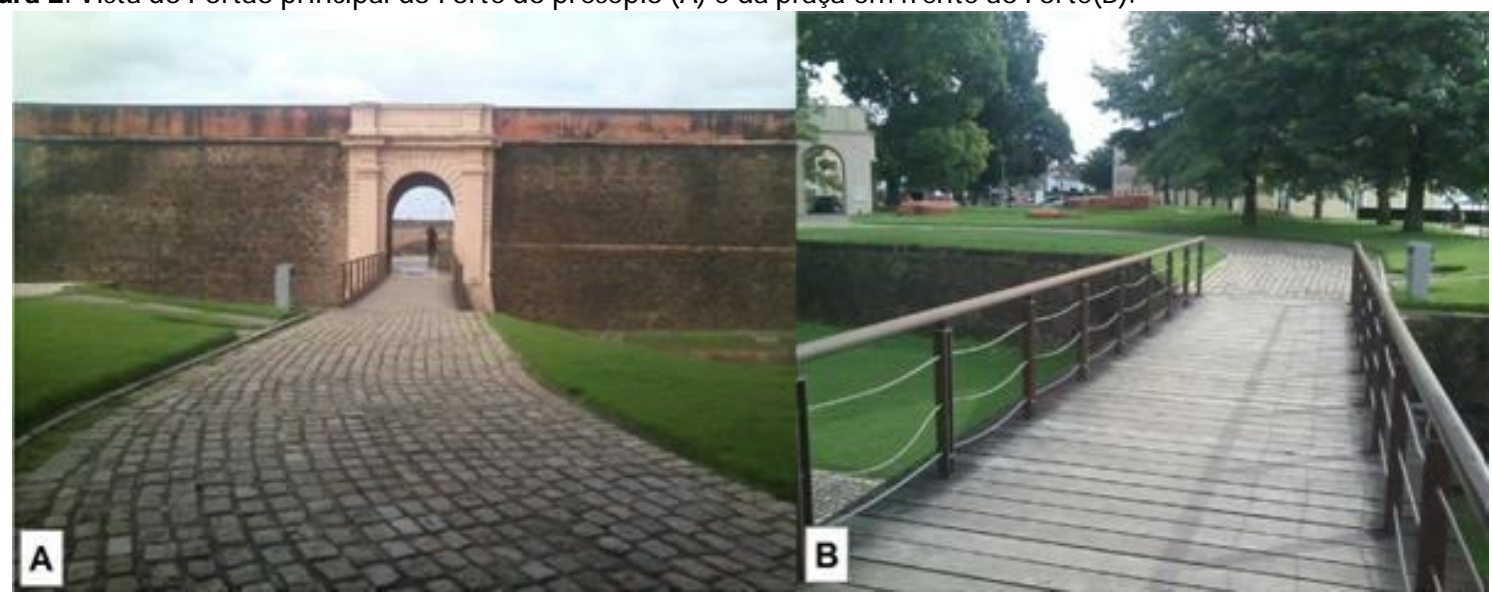

Praça do Jaú

Situada no Bairro Sacramenta em Belém, a praça é limitada em uma das extremidades pela Avenida Senado Lemos, importante via de ligação entre o bairro e a área central de Belém (Figura 2A). A praça com um traçado das vias de passeio com um misto de curvas e retas é bastante arborizada constituindo um espaço agradável do ponto de vista paisagístico. Com equipamentos de academia ao ar livre a praça tornou-se ponto de encontro para a prática de exercícios físicos pelos frequentadores (Figura 2B). 
Figura 3: Vista da Praça do Jaú ladeada pela avenida senador Lemos (A) e frequentadores praticantes de exercícios físicos rotineiros(B).

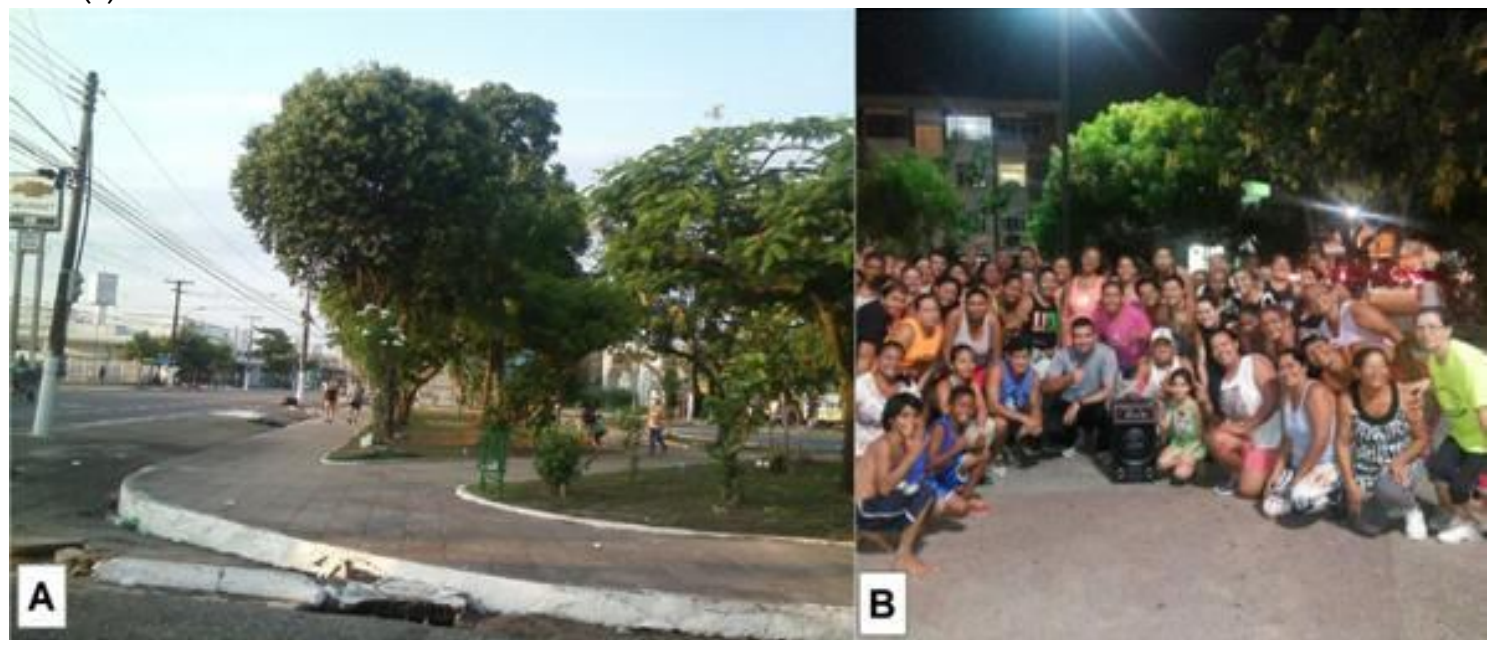

A Praça do Jaú abriga no momento, uma associação voluntária informal para a prática de exercícios físicos direcionados a manter o condicionamento físico e a qualidade de vida dos moradores do bairro. De acordo com os depoimentos colhidos essa ação surgiu de forma espontânea, unindo as pessoas em torno desse objetivo comum no espaço da praça. De um lado estavam os praticantes rotineiros de atividades físicas, sem orientação adequada e de outro alguns profissionais de educação física que moram nos arredores.

A solidariedade, somada aos encontros informais e cotidianos levaram os participantes a unirem-se e se organizarem formando um grande grupo que passou a se reunir de maneira sistemática. Essa associação resultou num grupo consolidado que se reúne todo finalzinho de tarde e começo da noite sempre sob a orientação de um profissional de educação física. Esse grupo organizou-se de forma espontânea, mas através do diálogo, do entendimento durante os encontros e hoje já dispõe inclusive de aparelhagem de som que proporciona que todos possam ouvir os comandos dos profissionais que direcionam os exercícios durante as aulas diárias.

\section{Praça Batista Campos}

A praça está situada no bairro homônimo, rodeada pelo centro comercial mais pulsante da cidade de Belém. Com vias de acesso internas quase sempre curvilíneas e elementos paisagísticos como os pequenos coretos (Figura 3B) que denotam tempos remotos, a praça se destaca na paisagem do bairro principalmente por apresentar uma arborização bastante madura. 0 denso arvoredo com dossel muito elevado, em alguns lugares da praça, praticamente esconde o concreto das fachadas dos arranhacéus nas imediações (Figura 3A). 
Figura 4: Aspecto do arvoredo denso (A) e do coreto principal na Praça Batista Campos (B).

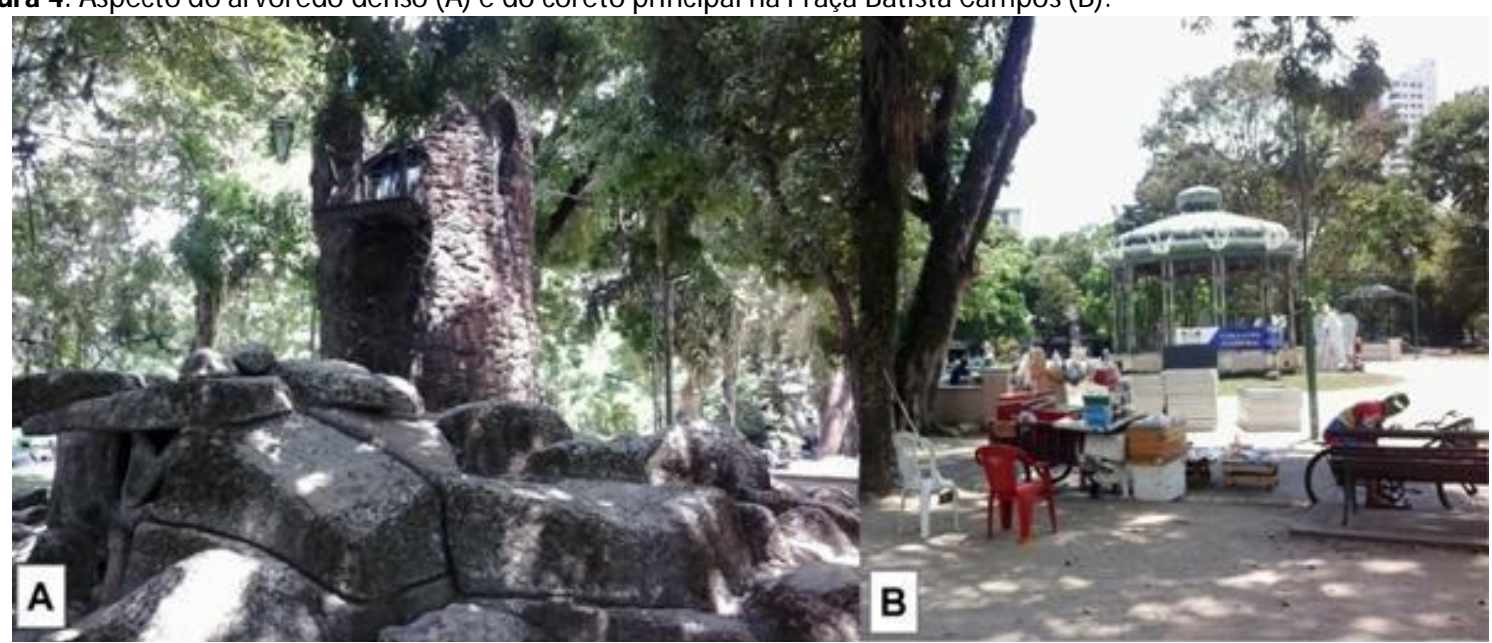

\section{VISITAÇÃO E USOS DAS PRAÇAS NA CIDADE DE MACAPÁ}

Em Macapá, a frequência de visitação na Praça do Forte (65\%), elevada, mas um pouco abaixo daquela encontrada nas praças da Conceição (91\%) e Chico Noé (92\%) reflete o fato de aquele lugar ser usado para usos mais específicos como reuniões de grupos ou familiares durante determinados dias e horários na semana. De outra forma, nas duas outras os usos mais comuns são a prática de esportes (Chico Noé, 44\%) e a contemplação da natureza (Conceição, 28\%) que atribuem à visitação um caráter de maior regularidade, mas também relacionados a determinados horários (Gráfico 3 , questões 2 e 3). Em todas as três praças foi possível encontrar pessoas que mesmo não sendo entrevistadas em seus respectivos lugares de trabalho, afirmaram que estavam ali para trabalhar ou no intervalo do trabalho (Gráfico 3, questão 3, opção “outros"). 
Gráfico 3: Comparação dos percentuais de respostas sobre a frequência de visitação, motivação e percepção de espaço público nos lugares pesquisados em M acapá.

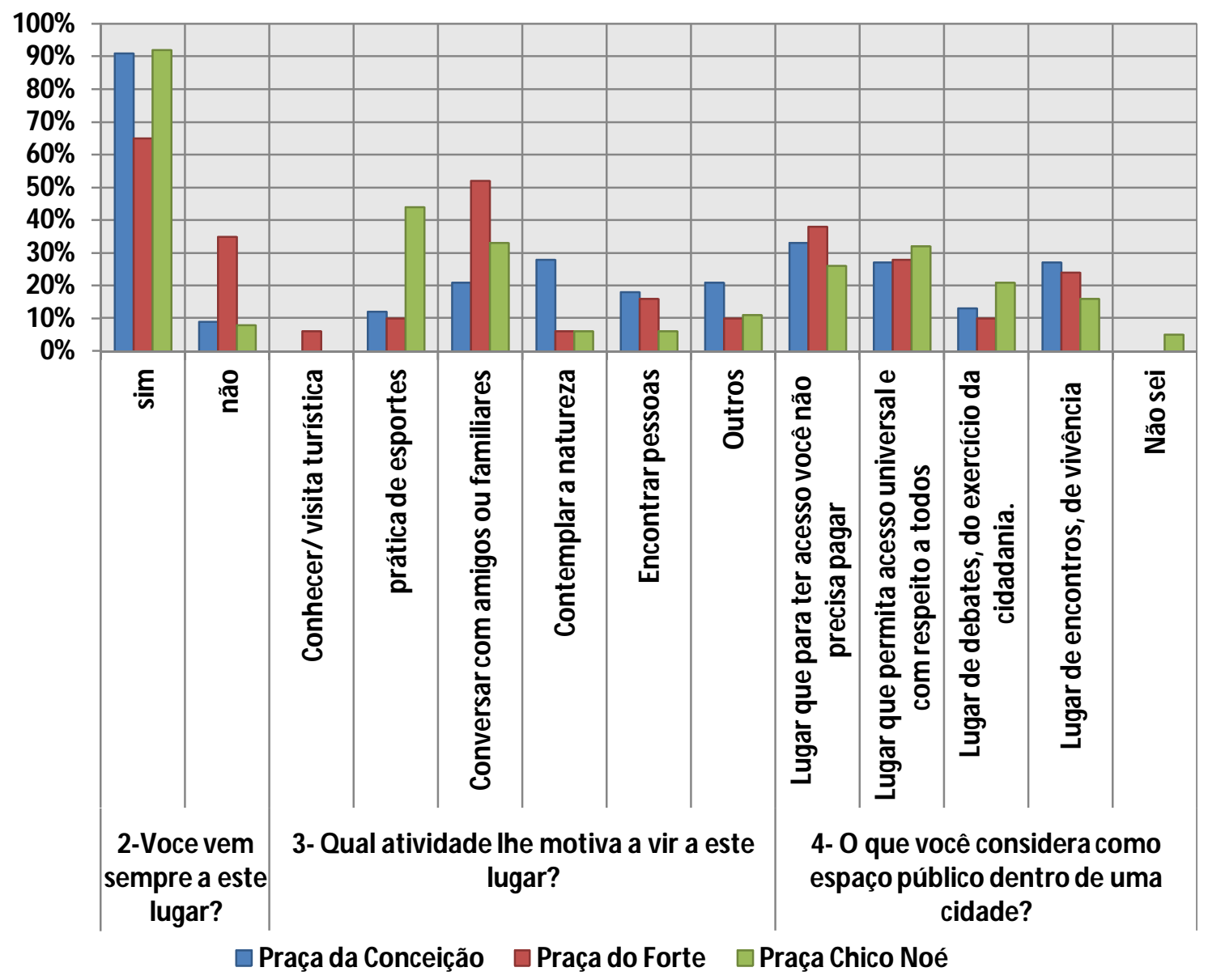

Em Macapá, a noção de espaço público nos três lugares pesquisados, apresenta percentuais de respostas quase sempre equilibrados, denotando o caráter mais diversificado dos usos em cada lugar. Os frequentadores das praças da Conceição, do Forte e Chico Noé, respectivamente, valorizam tanto a noção relacionada ao acesso livre, sem precisar pagar (32\%, 38\% e $27 \%)$ quanto ao acesso universal e respeitoso $(28 \%, 29 \%$ e $32 \%)$. Também se registraram noções relacionadas ao debate e exercício da cidadania $(12 \%, 10 \%$ e $21 \%)$, e ao encontro e as vivências cotidianas, $27 \%, 23 \%$ e $18 \%$, respectivamente (Gráfico 3, questão 4).

Em relação à segurança, nos lugares pesquisados em Macapá, talvez em função da permanência das pessoas apenas em determinados dias ou horários, prevalece também para os pesquisados, a sensação de segurança em determinados horários ou dias da semana (50\% na Praça da Conceição, 60\% na Praça do Forte e 46\% na Praça Chico Noé). A maior sensação de insegurança (54\%) na Praça Chico Noé, situada no Bairro do Pacoval, também reflete sua localização e seu uso mais frequente que é a prática de esportes, atividade concentrada em horários e dias específicos por grupos de pessoas que se organizaram para essa atividade no local (Gráfico 4, questão 5). 
Gráfico 4: Comparação dos percentuais de respostas sobre a sensação de segurança, reconhecimento do espaço público, responsabilidade com a preservação e reconhecimento da importância para uma vida mais saudável na cidade de Macapá.

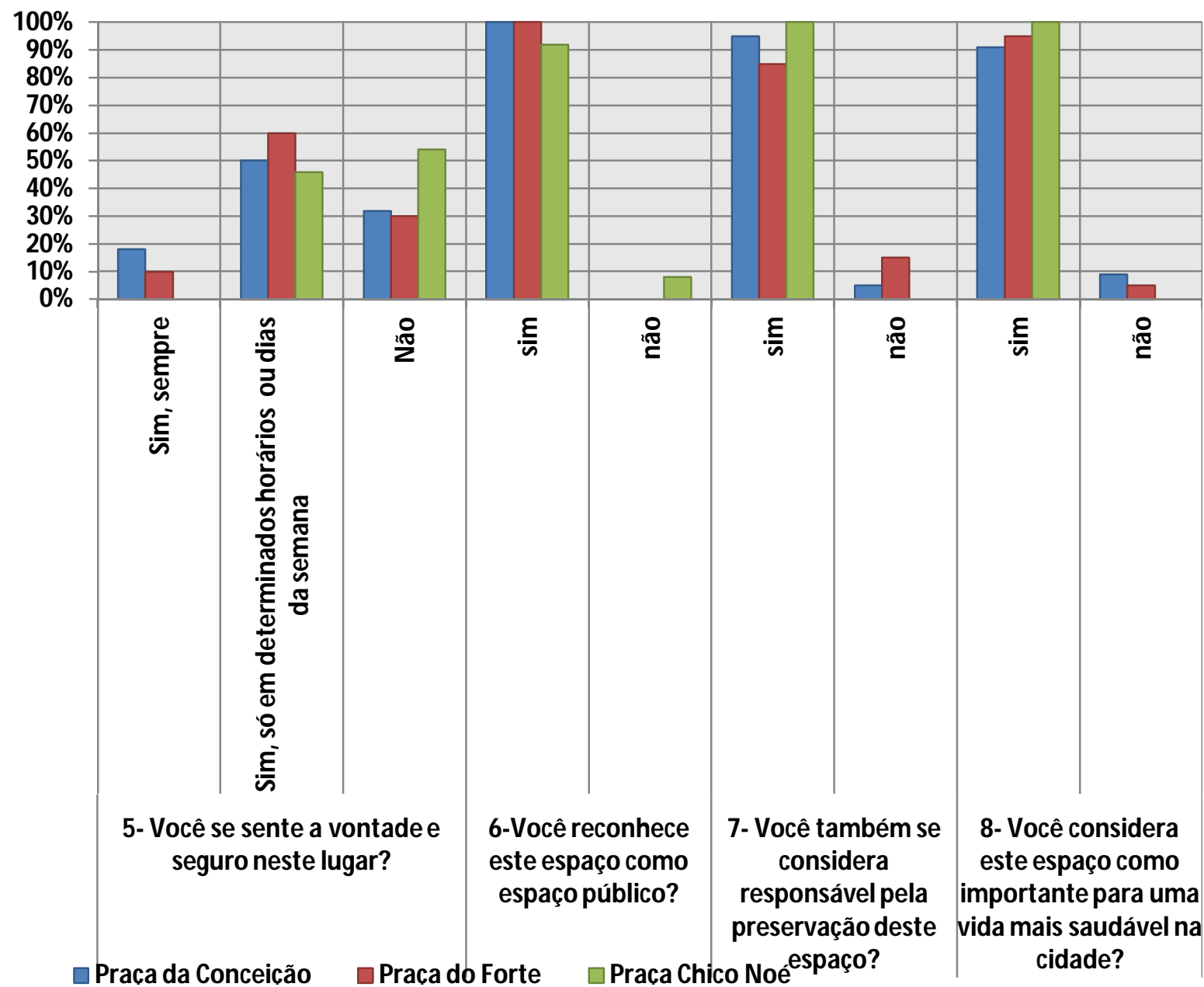

Os pesquisados nas praças da cidade de Macapá também foram unânimes no reconhecimento desses lugares como espaço público (100\% nas praças da Conceição e do Forte e $91 \%$ na Praça Chico Noé). De igual maneira, 95\% dos pesquisados na Praça da Conceição, $85 \%$ na Praça do Forte e 100\% na Praça Chico Noé, se consideram responsáveis pela preservação destes espaços. Também se percebeu ratificado entre os pesquisados (90\%, 95\% e $100 \%$ respectivamente), a importância das praças para uma vida mais saudável na cidade (Gráfico 4, questões 6,7 e 8).

\section{Praça da Conceição}

Situada no bairro do trem, um dos bairros da área mais central de Macapá, a praça é uma das mais antigas e tradicionalmente vocacionada às reuniões futebolísticas. A praça recebeu este nome por ter sido construída em frente à Igreja de nome homônimo (Figura 4A). Com traçado de vias internas misto de curvas e retas, a praça apresenta arborização jovem, quadras de esportes (Figura 4B) e um campo de areia. No 
campo de areia é realizada anualmente a tradicional copa Marcílio Dias de Futebol, realizada pela Associação de Solteiros e Casados do Bairro.

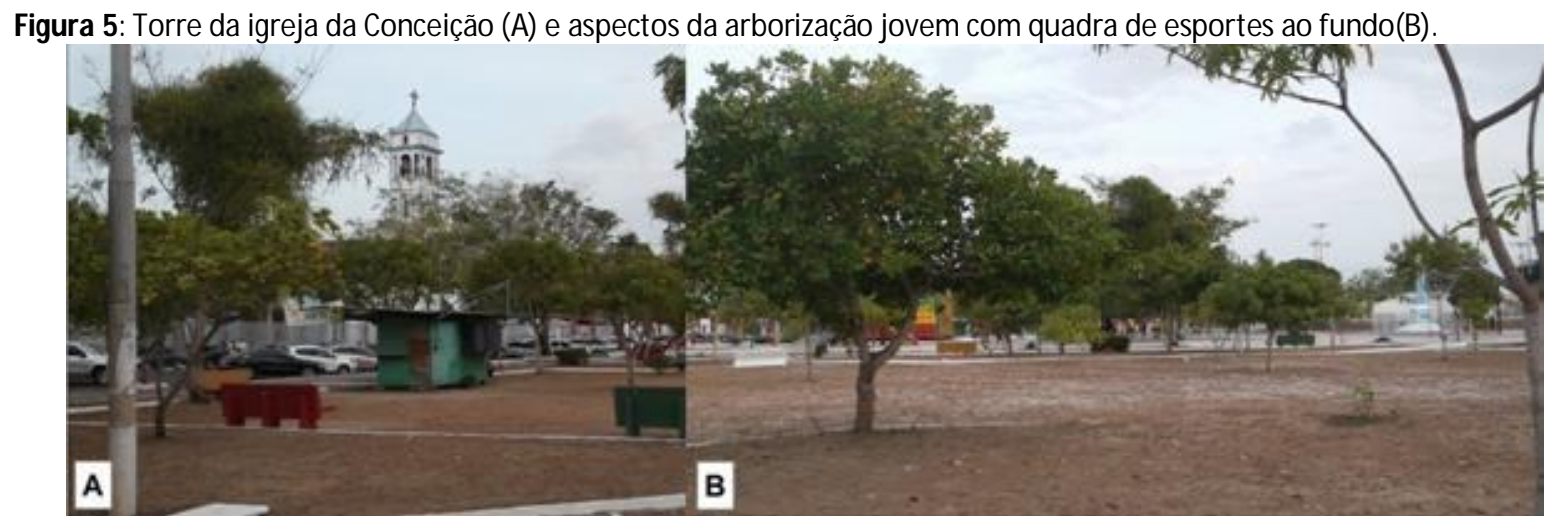

Praça do Forte

A Praça do Forte, situada na borda direita da Fortaleza de São José de Macapá, foi erguida no lugar que ficou conhecido até o início da década de 1980 como "Baixada da Vacaria". A praça apresenta vias internas mista de curvas e retas, estacionamento, parquinho e chafariz (Figura 5A). Um dos maiores atrativos da praça é sua localização privilegiada ao lado da fortaleza e ás margens do rio Amazonas (Figura 5B).

Figura 6: Aspecto da área central da Praça do Forte (A) e vista da orla do Amazonas com Fortaleza de São José de Macapá ao fundo(B).

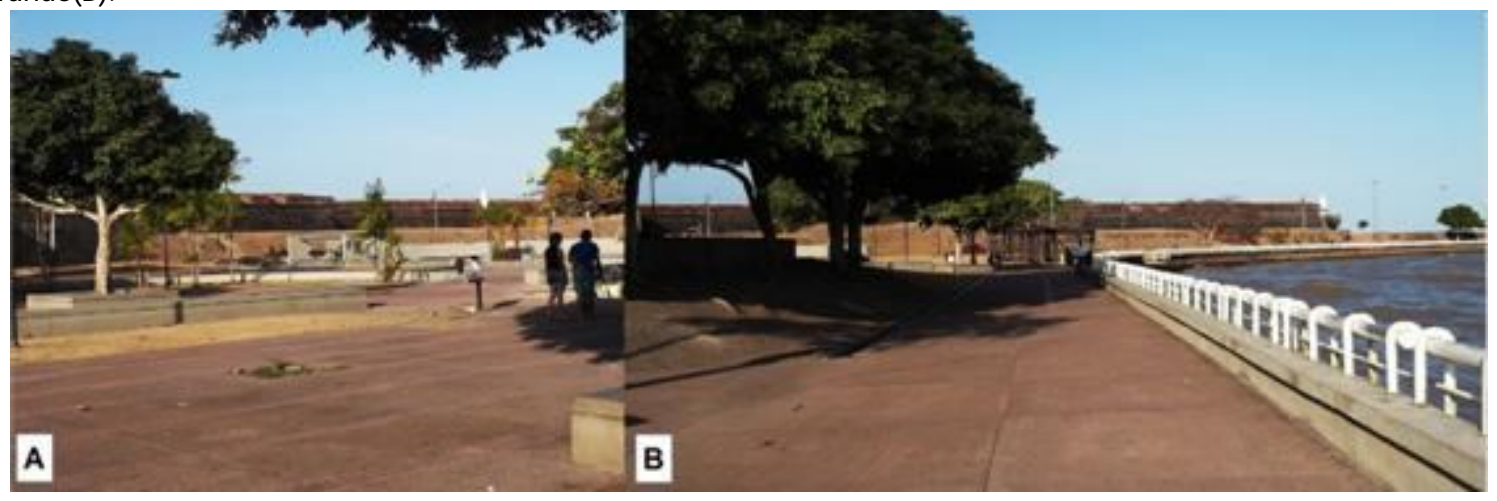

\section{Praça Chico Noé}

Situada no Bairro do Pacoval na zona norte da cidade de M acapá, a praça apresenta vias internas mista de curvas e retas. Possui quadras de esportes, campinho de areia e parquinho infantil. A Praça Chico Noé era a única praça da cidade com piscina social desativada no início desta segunda década do século XXI, é também, uma das duas únicas com arena teatral (Figura 6A). Apesar de apresentar boa e jovem arborização em sua porção oeste e no contorno, a área mais central da praça apresenta-se com pouca ou nenhuma arborização. Na porção leste da praça, uma área é utilizada diariamente a grupos organizados para a prática de exercícios de condicionamento 
físico orientado (Figura 6B).

Figura 7: Aspecto da área central da Praça Chico Noé (A), com destaque para a arena de teatro e grupo organizado em horário para a prática de esportes(B).

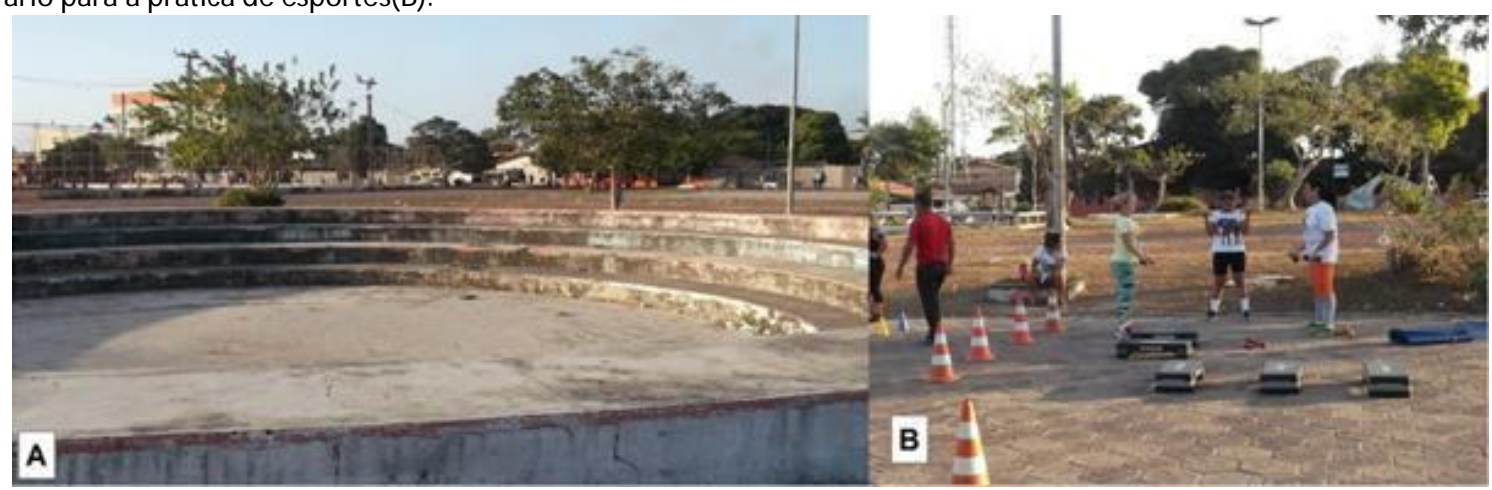

\section{COMPARATIVO DA FREQUÊNCIA DE VISITAÇÃO E USOS DOS ESPAÇOS PÚBLICOS EM BELÉM E MACAPÁ}

Os espaços das praças ainda são visitados com muita frequência, tanto na grande Belém (72\%) quanto em Macapá (82\%), (Gráfico 5, questão 2). Nas duas cidades, a prática de esportes e conversar com amigos ou familiares são as atividade que mais motivam os frequentadores, 31\%, e 19\% em Belém, 18\% e 35\% em Macapá respectivamente (Gráfico 5, questão 3). Entretanto, o uso mais frequente em Belém (prática de esportes, 31\%) e Macapá (conversar com amigos ou familiares, 35\%) está quase sempre relacionado a determinados dias ou horários, o que ratifica o seu caráter esporádico. Essa esporadicidade dos usos pode ser ao mesmo tempo causa e consequência da falta de sensação de segurança, pois $42 \%$ dos pesquisados em Belém e $52 \%$ em Macapá só se sentem seguros para frequentar esses lugares em determinados dias ou horários (Gráfico 6, questão 5). 
Gráfico 5: Comparação dos percentuais totais de respostas sobre a frequência de visitação, motivação e percepção de espaço público em Belém Macapá.

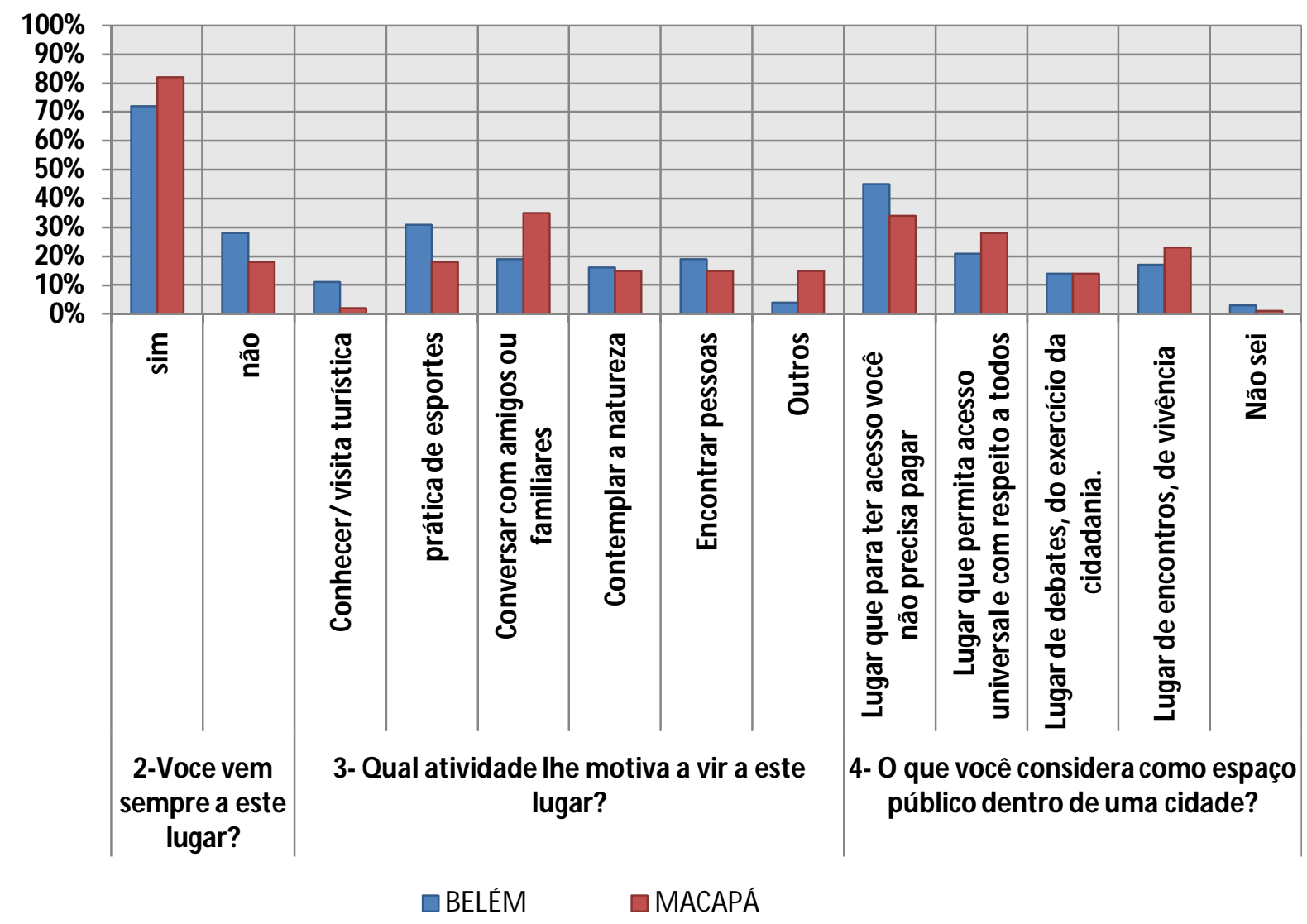

Apesar dos usos específicos, os frequentadores das praças nas duas cidades, ratificam fortíssimo comprometimento com esses espaços. Há praticamente unanimidade em relação ao reconhecimento das praças como espaço público (93\% dos pesquisados em Belém e $98 \%$ em Macapá). Os pesquisados também se sentem responsáveis com a preservação do espaço das praças ( $90 \%$ em Belém e $92 \%$ em Macapá) e afirmam que esses espaços são importantes para uma vida mais saudável nessas cidades (98\% em Belém e 94\% em Macapá), (Gráfico 6, questões 6,7 e 8). 
Gráfico 6: Comparação dos percentuais de respostas sobre a sensação de segurança, reconhecimento do espaço público, responsabilidade com a preservação e reconhecimento da importância para uma vida mais saudável em Belém e Macapá.

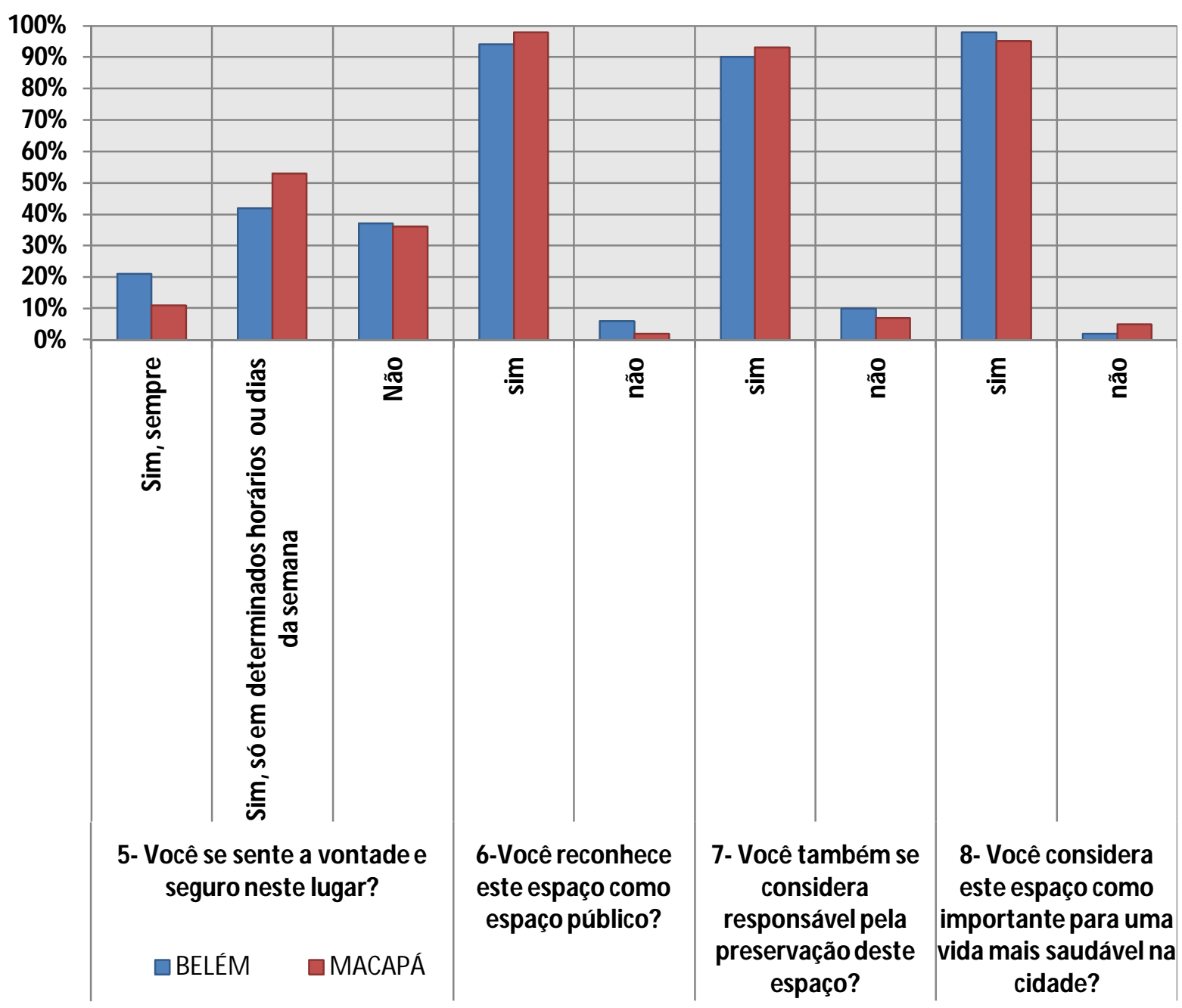

\section{SOBRE AS PRÁTICAS ESPACIAIS E O AGIR OU INTERVIR DO ESTADO NO ESPAÇO DAS PRAÇAS NAS DUAS CIDADES}

Pelos resultados apresentados para ambas as cidades sentir-se seguro é uma condição determinante tanto para a frequência de visitação quanto aos usos mais comuns. Em pleno século XXI, as ações governamentais no espaço das praças visitadas parecem estar voltadas principalmente àquilo que se tem insistido ser uma "revitalização" feita de forma muitas vezes desconectada do próprio contexto histórico ou mesmo físico-estrutural. Isso parece bem presente no complexo Feliz Lusitânia em Belém e no Parque do forte em Macapá. Nessas praças os elementos cênicos parecem divorciados litigiosamente dos seus contextos históricos e da vida social que os circunda, que deveria servir de alvo para as informações históricas que seus objetos principais (Forte o Presépio em Belém e Fortaleza de São José em Macapá) carregam.

Nas praças de Macapá e Belém a virtualidade dos objetos explícitos em longos tex- 
tos e com uma diversidade de imagens, disponíveis em qualquer tablet ou smartphone, portado eventualmente pelos frequentadores parece também invadir a realidade virtualizando o convívio. Aquelas placas informativas já não existem mais, a arte e a história devem primeiro ser buscadas em páginas de internet para depois, eventualmente serem vividas e sentidas, quando der, ao vivo e em cores. Mas em alguns espaços reais, como é caso do acesso interno aos fortes, o viver e o sentir, mais do que regulados, como de fato devem ser, são extremamente superficiais, pois mesmo nesses espaços não se tem alguém para trocar ou viver as informações históricas que eles carregam. A virtualidade que valoriza os objetos pode ao mesmo tempo desvalorizar em boa medida a convivência, as trocas sociais. 0 motivo das praças são as pessoas, ou pelo menos deveriam ser os objetos não podem estar ali em detrimento da vida que os circunda.

Entre as questões que se levantam diante do quadro apresentado na pesquisa uma remete ao fato de que nossas praças, nos horários e dias mais frequentados, tornaram-se lugares com práticas espaciais quase exclusivas de grupos organizados em torno de um objetivo comum. Esses grupos, mais ou menos fechados em sí, organizam-se em horários específicos e pré-determinados. Foi interessante notar ao longo das abordagens que os grupos organizados, enquanto participavam de suas atividades, poucos interagiam com outros grupos ou com as demais pessoas, externas a ele, que também frequentavam o espaço das praças. Nem mesmo um simples convite aos passantes ou cumprimento fora dos círculos grupais organizados. Centrados em suas atividades, os grupos parecem encontrar na praça algo muito mais parecido como academias ou templos religiosos do que um espaço público propriamente.

A esfera pública parece ter-se tornado uma névoa tênue que se dissipa diante do sol da indiferença instigada pela violência ou pelo medo da violência que parece a toda hora circundar o espaço das praças. Esse tipo de comportamento aliena o espaço nas mentes dos frequentadores equivalendo o público do espaço das praças a uma massa inerte e indiferente, que vez ou outra se transforma numa multidão despertada por eventuais eventos sociais como shows comemorativos de datas importantes.

Embora contraditória do ponto de vista da concepção teórica ideal do espaço público, a apropriação das praças pelos grupos organizados é uma solução possível para combater a violência, sobre esse comportamento, Jacobs (2007) já anunciara que a ausência de vida social no espaço público é sempre um vazio preenchido pelas mais diversas formas antissociais de apropriação. A violência e o medo da violência nas praças podem ser consequência exatamente da falta de um convívio social mais presente.

No momento atual, as soluções apresentadas pelo Estado, quase sempre correspondem a ações que visam reprimir o agente da violência em vez de fomentar um convívio social mais presente nesses espaços. Ao que tudo indica, há necessidade de um repensar do planejamento em âmbito metropolitano ou mesmo municipal e estadual adequado à realidade desses espaços. Nesse planejamento há que se conside- 
rar tanto a manutenção periódica dos objetos quanto as maneiras de fomentar a maior e mais diversificada participação dos agentes que nele interagem.

\section{CONSIDERAÇÕES FINAIS}

Como resultado elementar deste estudo, percebeu-se que a maior frequência de visitação e o uso dos espaços público das praças pelas pessoas nas cidades de Belém e Macapá tornou-se esporádica, restrita a determinados dias e horários. Entretanto, mais de $90 \%$ dos pesquisados nas duas cidades, reconhecem as praças como espaços públicos importantes para a preservação e valorização de uma vida mais saudável nessas cidades. Esse posicionamento não só ratifica importância das praças como espaços públicos que proporcionam o desenvolvimento de práticas espaciais coletivas, mas que fomentam nesse coletivo, o encontro e o debate, fundamentais no processo de revalorização desses espaços. Sobre essa dinâmica e poder das práticas espaciais no espaço público das praças, ainda que aparentemente carregadas de um sentido grupal de isolamento.

Nas duas cidades, os espaços das praças abrigam preponderantemente atividades como a prática de esportes (Belém) e os encontros familiares ou grupais (M acapá), restritas a determinados dias e horários. Essas atividades, aparentemente induzem a relações mais fortuitas no espaço público, mas nem por isso, seus organizadores e participantes, tanto em Belém quanto em Macapá, deixam de ter uma preocupação constante sobre a importância desses espaços para o debate, 0 encontro, as vivências e o respeito à cidadania.

0 forte comprometimento com o direito às vivências, as práticas espaciais nas cidades de Belém e Macapá, remetem aquele direito à cidade lefebriano. Os usos, ainda que por grupos e atividades específicas e relacionadas a horários e dias da semana, não apenas enaltecem e auxiliam a pensar o espaço público de uma nova forma, também exigem o direito a esse espaço e lhe ratificam sua importância. De igual maneira, é preciso encontrar formas de fazer com que essas percepções e usos presentes sejam transformados em projetos e ações que auxiliem a imprimir ainda mais 0 valor de uso nesses espaços.

0 que se pode sugerir ao poder público, aos governos municipal e estadual sobre a situação atual do espaço públicos das praças nas duas cidades? Quais elementos deveriam servir de base pra repensar o agir e não apenas o "intervir" nesses espaços? De pronto deve-se sugerir exatamente a mudança de concepção acerca de como planejar o espaço das praças. Não se pode apenas pensar as eventuais "revitalizações" dos objetos que os compõe, pois a sensação de segurança e confiança que tanto se percebeu valorizada pelos frequentadores, não pode ser proporcionada apenas pela dotação de novos objetos, mesmo aqueles voltados à "vigilância" como os tão propalados sistemas de vídeo-segurança implantados já em diversos logradouros públicos pelo país afora e que podem ser uma consequência antes de ser uma solução para a violência ou medo 
da violência. Nesse sentido, Souza alerta que mais do que dar segurança objetos como estes poderiam representam exatamente a sensação de falta dela, pois, todos acabam sendo alvo de um controle social televisionado.

São as pessoas em sua participação ativa no espaço das praças que podem dar vida e sentido às práticas que nelas se processam. Pensar segurança deve ser, portanto pensar e planejar o cotidiano vivido nesses espaços públicos. Não basta apenas meIhorar o sistema de iluminação dos postes, deve-se pensar a iluminação dos encontros, da vida nas praças, se há práticas grupais para a prática de esportes, porque não pensar projetos de incentivo a essas práticas? Porque não incluir no planejamento dos órgãos competentes atividades deslocando agentes públicos para interagir e auxiliar no desenvolvimento dessas práticas?

De outra forma, o poder público, em seu planejamento deveria valorizar esses espaços fomentando um acompanhamento mais de perto das práticas sociais que nele se processam, não penas deslocando contingentes policiais armados, mas agentes que possam auxiliar em outras áreas como história, turismo e assim por diante. Não se sugere uma participação permanente desses agentes no espaço das praças, mas assim como se procurou fazer durante esta pesquisa, que seja um acompanhamento que permita ver a vida e, portanto as práticas espaciais que se processam nesses espaços nos momentos de maior frequência. Talvez a partir dessas interações, outras atividades, outros caminhos de planejamento e novas e inovadoras práticas espaciais sejam possíveis para 0 espaço das praças públicas em Macapá e Belém.

\section{REFERÊNCIAS}

GOM ES, Paulo César da Costa. Espaços públicos: um modo de ser do espaço, um modo de ser no espaço. In: CASTRO, I, E; GOM ES, P.C. C; CORREA, R.L. Olhares geográficos: modos de ver e viver o espaço. Rio de Janeiro: Bertrand Brasil, 2012.p.19-41.

HARVEY, David. Cidades rebeldes: do direito à cidade à revolução urbana. São Paulo: Martins fontes, 2014.

JACOBS, Jane. M orte e vida das grandes cidades. Tradução Carlos S. M endes Rosa - $1^{\text {a }}$ Edição, 2000. São Paulo: Martins fontes, (4ạ. tiragem), 2007.

LEFEBVRE, Henri. 0 direito à cidade. São Paulo: Centauro, 2001.

. A produção do espaço. Trad. Doralice Barros Pereira e Sérgio Martins (do original: La production de l'espace. 4ed Paris: Éditions Anthropos, 2000). Primeira versão: início - fev.2006.

LEITE, Rogério Proença. Política dos usos: a construção dos lugares no espaço público. In: LEITE, Rogério Proença. da cidade: lugares e espaço público na experiência urbana contemporânea. Campinas, SP: Editora da UNICAM P; Aracaju, SE: Editora UFS, 2004. SANTOS, Milton. A natureza do espaço: técnica e tempo, razão e emoção. 3. ed. São Paulo: Hucitec, 1999.

SOUZA, M arcelo Lopes de. Cidades fragmentadas, medo generalizado: das "áreas de 
risco" a "ubiqüidade do risco". In: . Fobópole: 0 medo generalizado e a militarização da questão urbana. Rio de Janeiro: Bertrand Brasil, 2008.

TRINDADE JR., Saint-Clair Cordeiro da. Territórios pensados e territórios vividos: apropriação do espaço e práticas urbanas de renovação urbana na área central de Belém. Grumo-N. 1. Rio e Janeiro: 7Letras, 2003.

Artigo recebido em 30 de maio de 2016. Aprovado em 13 de outubro de 2016. 